\title{
Pelatihan Pembuatan Video Pembelajaran Bagi Guru SMA Karya Ibu Palembang
}

\author{
Nyiayu Fahriza Fuadiah¹, *Marhamah², Eka Fitri Puspa Sari ${ }^{3}$ Jumroh $^{4}$, Lusiana ${ }^{5}$ \\ 1,2,3,4,5Universitas PGRI Palembang, Palembang, Indonesia
}

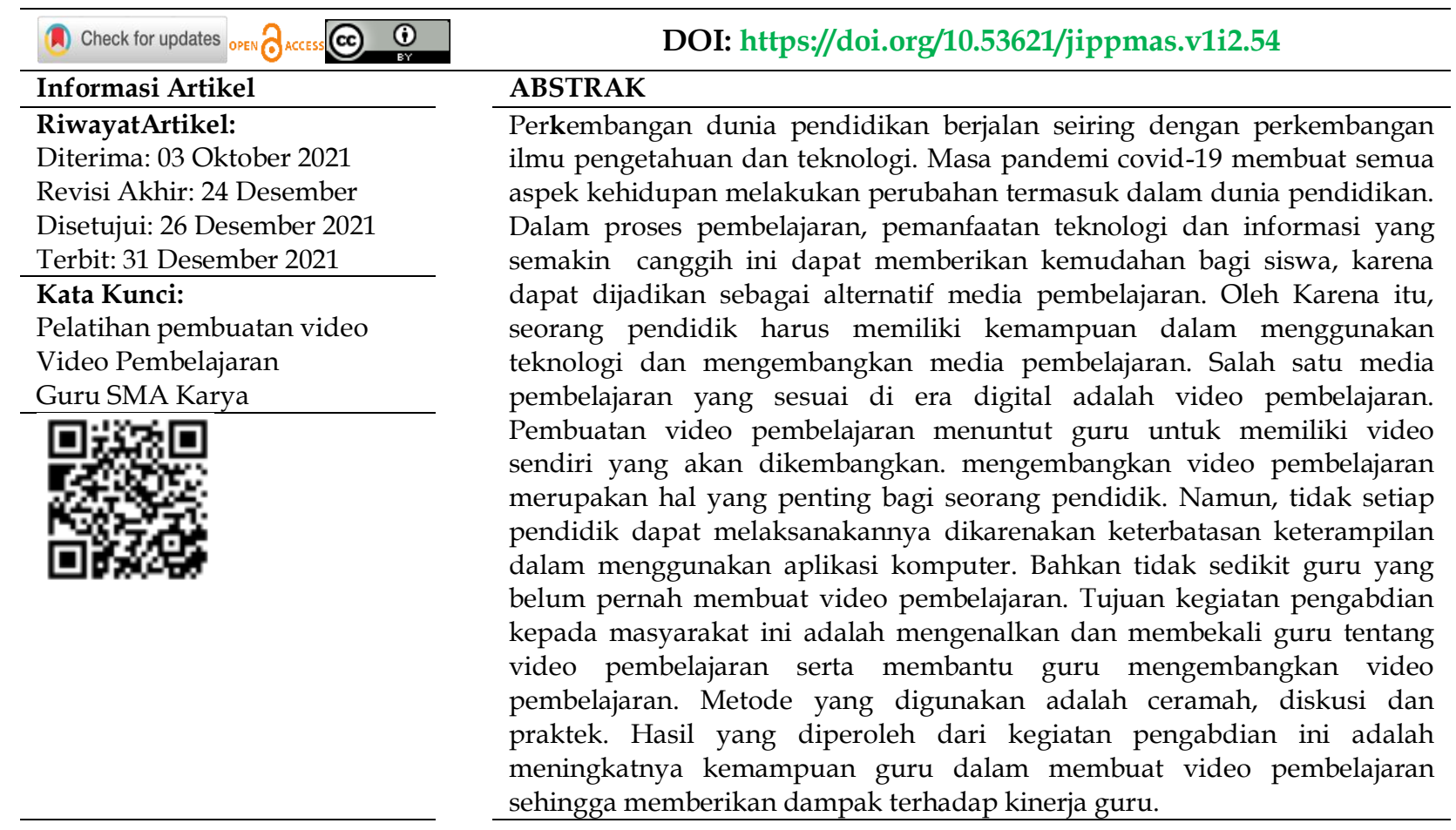

\section{PENDAHULUAN}

Peningkatan mutu pelaksanaan pembelajaran disekolah dilakukan dengan berbagai strategi, salah satu diantaranya melalui pengembangan bahan ajar yang digunakan, pelaksanaan pembelajaran,dan pengembangan prosedur penilaian (Al-Azri \& AlRashdi, 2014; Hermawan, Permasih \& Dewi, 2012). Terkait dengan pengembangan bahan ajar, saat ini pengembangan bahan ajar dalam bentuk video pembelajaran menjadi kebutuhan yang sangat penting karena dipandang sebagai salah satu media pembelajaran yang paling efektif (Kamlin \& Keong, 2020).

Pembelajaran adalah sebuah proses komunikasi antara siswa, guru, dan bahan pembelajaran yang terjadi pada suatu lingkungan belajar untuk mencpai tujuan pembelajaran (Suardi, 2018; Rohmawati, 2015). Komunikasi dalam pembelajaran tidak akan berjalan tanpa bantuan sarana penyampai pesan atau media agar pesan dapat diterima dengan baik dan memberikan dampak yang positif kepada peserta didik (Masdul, 2018). Pesan yang akan dikomunikasikan adalah isi pembelajaran yang ada dalam kurikulum yang dituangkan oleh pengajar atau fasilitator atau sumber lain ke dalam simbol-simbol komunikasi, baik simbol verbal maupun simbol non verbal atau visual. Media pembelajaran sebagai salah satu alat yang digunakan guru sebagai penyampai pesan hendaknya dipandang sebagai bagian integral dari suatu sistem pembelajaran dan bukan hanya sebagai alat bantu yang berfungsi sebagai tambahan 
yang digunakan bila dianggap perlu dan hanya dimanfaatkan sewaktu-waktu (Ekayani, 2017; Tafonao, 2018).

Menurut Sadjati (2003) yang termasuk kategori video ialah segala sesuatu yang memungkinkan sinyal audio dapat dikombinasikan dengan gambar bergerak secara sekuensial.Video termasuk dalam kategori bahan ajar audio visual. Bahan ajar audio visual atau bahan ajar pandang-dengar rmerupakan bahan ajar yang mengkombinasikan dua materi, yaitu: materi visual dan auditif. Materi visual ditunjukan untuk merangsang indra penglihatan siswa sedang materi auditif untuk merangsang indra pendengaran mereka. Dengan kombinasi dua materi ini, pendidik dapat menciptakan proses pembelajaran yang lebih berkualitas karena komunikasi berlangsung secara lebih efektif (Prastowo, 2014).

Salah satu aplikasi teknologi yang bisa digunakan untuk membuat video pembelajaran yaitu camtasia studio (Wahyuni, Adnyani, \& Pratiwi, 2020). Camtasia studio merupakan perangkat lunak (software) yang dikembangkan oleh TechSmith Coorperation khusus bidang multimedia. Camtasia studio adalah sebuah perangkat lunak yang digunakan untuk merekam semua aktifitas yang ada di desktop komputer secara penuh atau sebagian yang dapat disertakan dengan perekaman suara (Hafizh, 2017). Camtasia dapat dimanfaatkan untuk membuat media pembelajaran berbasis multimedia dan e-learning yaitu dengan membuat video tutorial atau pelatihan dan membuat video presentasi. Media pembelajaran berbasis aplikasi camtasia studio dapat membantu siswa menemukan konsep pembelajaran dengan cara menalar karena materi ditampilkan dalam bentuk objek berupa video yang berisi suara berupa instrumental music dan rangkaian gambar (Hafizh, 2017).

Pandemi Covid 19 di awal tahun 2020 menjadi titik perubahan dalam dunia pendidikan khususnya dalam proses pembelajaran. Kondisi pandemi membuat perubahan disemua aspek kehidupan termasuk pendidikan mengingat jarak, waktu, dan lokasi yang serba terbatas (Herliandry, Nurhasanah, \& Kuswanto, 2020). Pemerintah Provinsi Sumatera Selatan mengambil kebijakan dalam dunia pendidikan dengan meniadakan pembelajaran tatap muka dan diganti dengan pembelajaran online mulai dari tingkat sekolah dasar sampai ke tingkat perguruan tinggi. Pelatihan yang mendukung pembelajaran online ini pun banyak dilakukan baik oleh pemerintah dan institusi pendidikan seperti perguruan tinggi, termasuk mengadakan pelatihan atau workshop pembuatan video pembelajaran. Di sisi lain, kondisi pendemi yang terjadi pada saat era revolusi Industri 4.0 mengehendaki perubahan cepat pada sistem pendidikan dari segala aspek, mulai dari manajemen, metode, strategi pembelajaran serta media pembelajaran yang beralih pada teknologi digital (Suwardana, 2018). Oleh karena itu keterampilan dalam membuat video sebagai media pembelajaran merupakan hal yang penting bagi seorang guru.

Terkait dengan pelatihan pembuatan media pembelajaran berupa video dengan aplikasi Camtasia menunjukkan hasil yang cukup baik. Seperti pelatihan yang diberikan untuk para guru diberbagai sekolah, selain bermanfaat untuk peserta didik juga dapat mengembangkan kreativitas guru (Budiono, Hakim, \& Affandi, 2021; Thohari, dkk, 2021; Sholeh, Suraya, \& Suraya, 2018). Selain itu aplikasi ini dapat dipelajari dengan mudah oleh guru dan dapat diakses kapanpun oleh peserta didiknya. Camtasia sendiri merupakan sebuah software untuk meng-capture (memotret) tampilan pada layar monitor yang dapat ditambah dengan audio dan video (Putra, Ariawan, \& Sutaya, 2019). Melalui aplikasi ini pengguna dapat merekam langsung tampilan presentasi power point dalam format video, narasi suara, dan 
webcam video. Video yang dibuat menggunakan Camtasia dapat disimpan dalam Web, iPad, iPhone,Youtube ataupun dibakar dalam keping CD/DVD dalam bentuk Avi, Mpg, Wmp, SWF, dan html.

Walaupun pembuatan video pembelajaran sekarang sudah dilengkapi dengan aplikasi yang lebih mudah seperti Camtasia, pada kenyataannya dilapangan masih banyaknya guru atau tenaga pendidik yang belum menguasai untuk membuat video pembelajaran itu sendiri. Bahkan tidak setiap pendidik dapat melaksanakannya dikarenakan keterbatasan keterampilan dalam menggunakan aplikasi komputer (Priwantoro, Fahmi, \& Ariesta, 2019). Selain itu masih banyak guru yang masih menggunakan media cetak yang sulit diakses secara online, dan kurangnya kemampuan guru dalam membuat media pembelajaran berbasis ICT (Abdullah, 2017). Kondisi seperti ini juga ditemukan oleh Tim Pengabdian Kepada Masyarakat Program Studi Pendidikan Matematika Universitas PGRI Palembang dari informasi yang disampaikan oleh guru di SMA Karya Ibu Palembang. Oleh karena itu, sebagai wujud dari salah satu Tri Dharma Perguruan Tinggi, Tim PKM merasa perlu melakukan kegiatan pelatihan pembuatan video pembelajaran dengan menggunakan aplikasi Camtasia bagi guru di SMA Karya Ibu Palembang.

\section{PERMASALAHAN}

Tim pengusul dan mitra sepakat untuk membuat skala prioritas permasalahan yang akan diselesaikan, meliputi :

1. Bagaimana meningkatkan wawasan dan pengetahuan guru berkaitan dengan pembuatan video pembelajaran?

2. Bagaimana melatih guru dalam membuat video pembelajaran?

\section{METODE PELAKSANAAN}

Metode yang telah diterapkan dalam kegiatan ini adalah pelatihan dan praktik pembuatan video pembelajaran yang pada pelatihan ini menggunakan aplikasi Camtasia yang dilaksanakan secara luring. Pelatihan dilaksanakan pada tanggal 7 Agustus 2021 sedangkan untuk pendampingan dilaksanakan pada tanggal 9 - 14 Agustus 2021. Dalam pelatihan ini telah diberikan beberapa kegiatan yang meliputi penyajian materi,dan praktik pembuatan video pembelajaran dengan menggunakan aplikasi Camtasia. Sesuai dengan permasalahan yang ada, khalayak sasaran dalam kegiatan PKM ini adalah guru-guru di SMA Karya Ibu Palembang sebanyak 25 orang bertempat di SMA Karya Ibu Palembang.

\section{PELAKSANAAN}

Langkah yang dilakukan oleh Tim PKM dalam kegiatan pelatihan ini meliputi:

1. Berkoordinasi dengan SMA Karya Ibu Palembang tentang kegiatan PKM yang akan dilaksanakan, seperti: Jenis kegiatan, sasaran kegiatan, peserta, serta system pelaksanaan melalui tatap muka dengan mematuhi protokol kesehatan dan secara daring. Tatap muka digunakan untuk pelatihan secara langsung yang dilaksanakan di laboratorium komputer, sedangkan daring sebagai pendampingan pembuatan e-book. Guru-guru ini selanjutnya menjadi khalayak sasaran dari kegiatan PKM ini. Karena keterbatasan kapasitas ruangan dan memenuhi protokol kesehatan, maka hanya 25 orang guru yang dapat mengikuti kegiatan ini.

2. Pemberian dan pengkajian materi pelatihan: tim pelaksana menyusun materi pelatihan berkaitan pembuatan e-book dengan menggunakan aplikasi Camtasia. 
Tim PKM juga menyusun jadwal pelatihan dan pemdampingan sampai didapatkan sebuah video pembelajaran untuk masing-masing guru yang mengikuti pelatihan.

3. Prosedur pelatihan: kegiatan ini dilaksanakan selama satu minggu untuk pelatihan dan pendampingan baik secara sikron maupun tidak sinkron. Pertemuan pertama sebagai pelatihan dilaksanakan pada hari Sabtu tanggal 7 Agustus 2021. Kegiatan pendampingan dilaksanakan setiap hari secara online melalui grup Whatsapp maupun di sekolah. Pada kegiatan pendampingan ini, peserta mendiskusikan beberapa hal terkait dengan materi pelatihan. Kegiatan pendampingan dilaksanakan pada tanggal 9 - 14 Agustus 2021.

4. Evaluasi kegiatan: evaluasi kegiatan PKM ini dilihat dari dua aspek, yaitu: (1) keterlibatan peserta dan (2) output kegiatan. Indikator keberhasilan kegiatan dilihat dari dua komponen evaluasi tersebut. Kegiatan PKM ini menargetkan kehadiran peserta $80 \%$ dari peserta keseluruhan. Output yang ditargetkan adalah dihasilkannya minimal $60 \%$ video dari peserta yang ikut pelatihan. Pada akhir kegiatan kegiatan, tim pelaksana dilakukan refleksi dan diskusi membahas pelaksanaan, penyampaian hal-hal yang perlu ditingkatkan, dan pemberian saransaran.

Berbagai metode digunakan dalam pelaksanaan pelatihan pembuatan video pembelajaran yaitu ceramah, diskusi dan praktek. Metode ceramah dan diskusi pada saat menjelaskan materi mengenai video pembelajaran dan metode praktik untuk mengetahui sejauh mana kemampuan guru dalam membuat video pembelajaran.

\section{HASIL DAN DISKUSI}

Tahap persiapan merupakan tahap awal sebelum pelaksanaan PKM. Dalam tahap ini ada beberapa hal yang telah dilakukan oleh tim, yaitu koordinasi internal yang dilakukan oleh tim PKM yaitu penentuan dan rekruitmen peserta pelatihan, pembuatan Instrumen PKM, seperti lembar presensi, angket dan persiapan publikasi, lokasi, dan dokumentasi.

\section{Kegiatan Pelatihan}

Kegiatan pelatihan yang dilakukan bertujuan untuk memberikan pemahaman terkait materi pengembangan media pembelajaran berbasis komputer. Untuk mendukung kegiatan pelatihan ini, tim PKM telah menyiapkan softfile berupa modul lengkap tentang pembuatan video dengan aplikasi Camtasia. Topik dan materi workshop dengan dibagi menjadi 4 sesi,yaitu: 1) pengenalan dan install aplikasi Camtasia; 2) cara menggunakan Camtasia Studio untuk membuat video pembelajaran; dan 3) import video pembelajaran ke aplikasi dan proses editing, dan 4) publish video pembelajaran ke berbagai format. Adapun aplikasi Camtasia dapat diunduh pada https://www.techsmith.com/video-editor.html baik dalam versi free ataupun berbayar. Beberapa dokumentasi kegiatan dapat dilihat pada Gambar 1 berikut. 


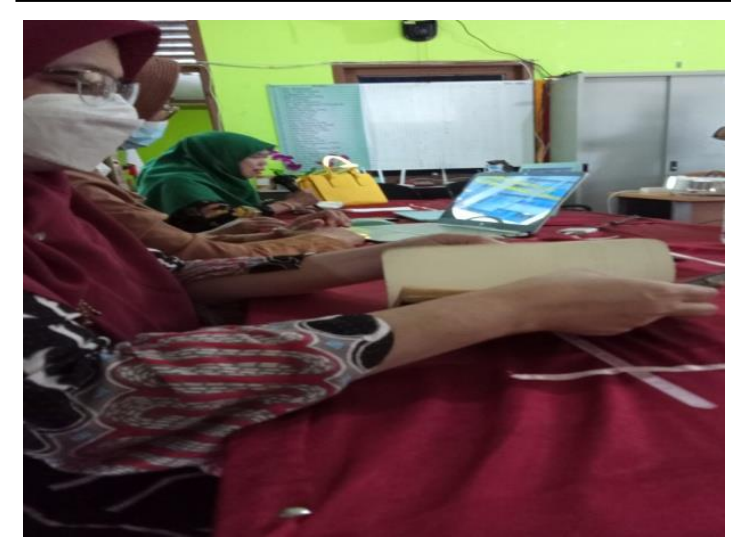

Gambar 1. Pembukaan

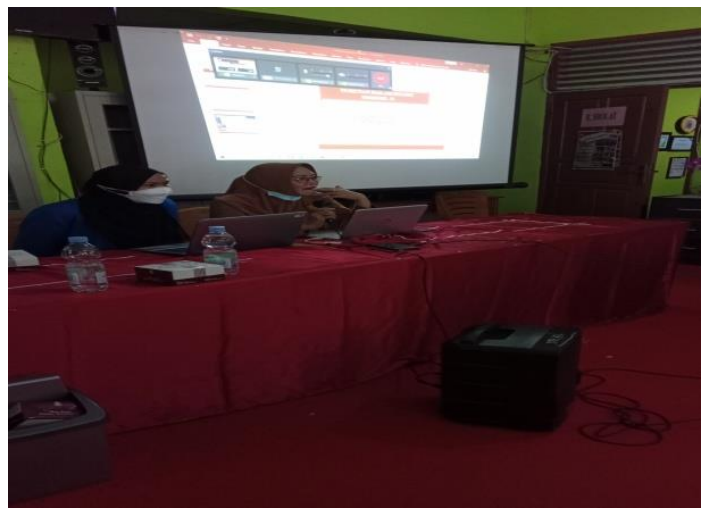

Gambar 3. Penyampaian Materi

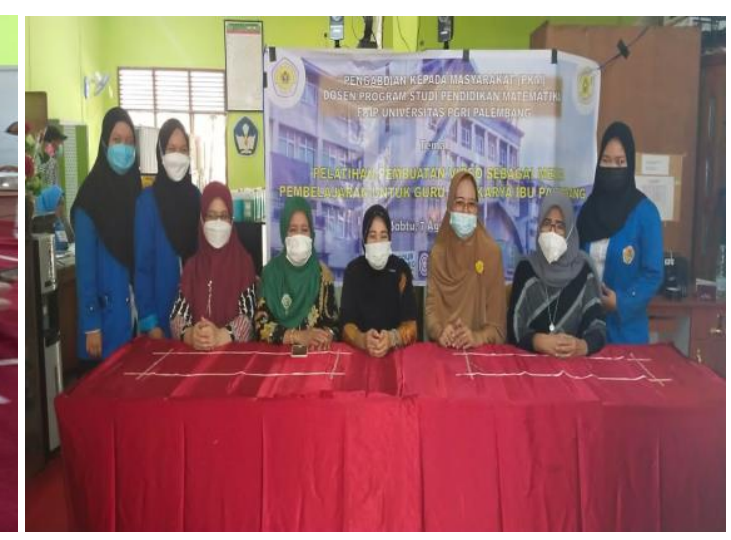

Gambar 2. Tim Pemateri

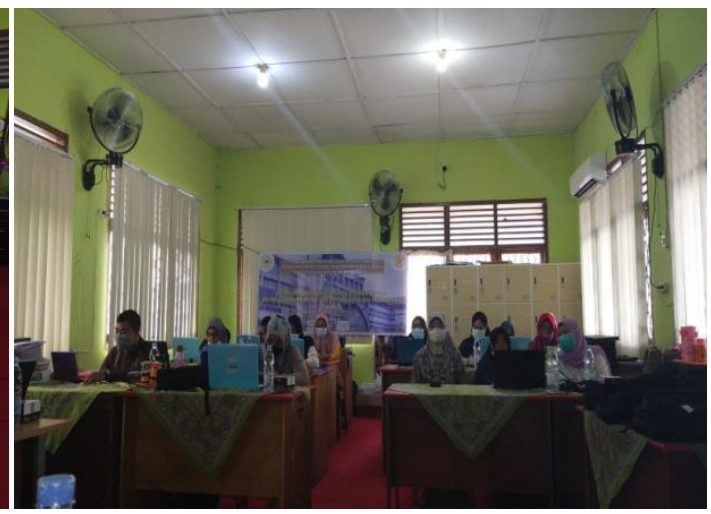

Gambar 4. Peserta PKM

Kegiatan pelatihan ini dilaksanakan di ruang laboratorium komputer dengan tetap memperhatikan protokol kesehatan yaitu melalui 3M (mencuci tangan, menjaga jarak, dan memakai masker).

\section{Kegiatan Pendampingan}

Pelatihan diawali dengan penyajian materi tentang pengertian video pembelajaran, pembuatan video pembelajaran, pengenalan dan penggunaan aplikasi camtasia.

Sesi berikutnya yaitu penugasan praktik berupa pendampingan. Peserta pelatihan diberi tugas praktik sesuai materi yang telah disajikan untuk menggali penyerapan dan pemahaman materi serta melihat kreativitasnya dalam berkarya. Dalam pelatihan ini para guru ditugaskan untuk membuat satu video pembelajaran terkait mata pelajaran yang diampu. Tim PKM mendampingi, memandu dan mengarahkan serta memberikan solusi apabila timbul permasalahan selama penugasan praktik. Pendampingan berfokus pada teknik dalam video dan audio editing berupa memperindah tampilan, penambahan suara pada video, menghilangkan atau menggabungkan bagian video, serta menggunakan Toolbars Add-Ins. Selain itu, dalam kegiatan pendampingan ini peserta pelatihan dapat mengajukan pertanyaan-pertanyaan terkait pembuatan video pembelajaran. Tindak lanjut video yang sudah dihasilkan kemudian didiskusikan bersama untuk mendapatkan hasil yang lebih baik dan layak untuk diaplikasikan dalam pembelajaran. Pada akhir pendampingan, seluruh peserta mengirimkan hasil karyanya melalui google drive yang sudah disiapkan oleh Tim PKM. Gambar 2 berikut merupakan dokumentasi kegiatan pendampingan. 

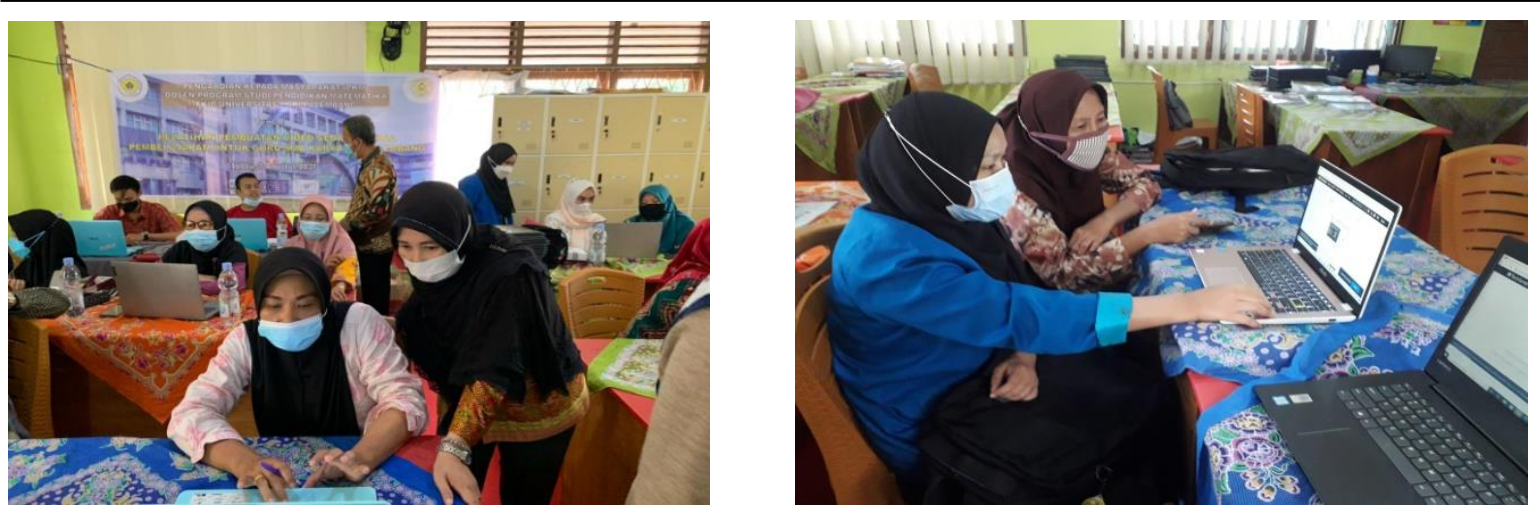

Gambar 5. Kegiatan Pendampingan

Salah contoh video pembelajaran yang dibuat oleh peserta pelatihan dapat dilihat pada Gambar 6 berikut.
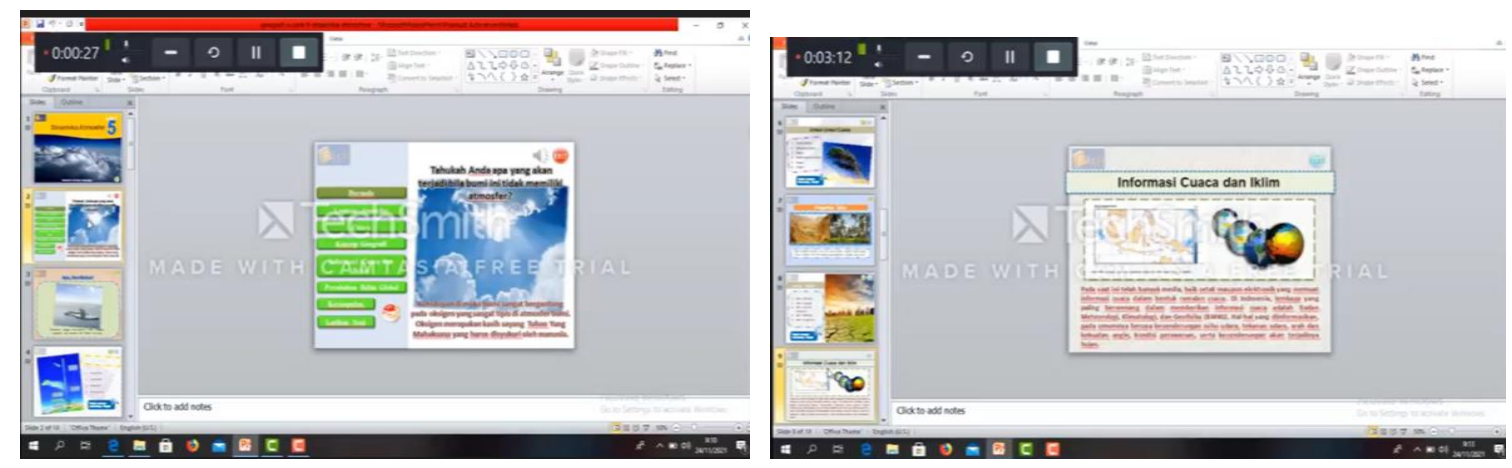

Gambar 6. Contoh video pembelajaran peserta pelatihan

Berdasarkan beberapa penelitian tentang penggunaan video sebagai media pembelajaran, video pembelajaran memiliki potensi untuk dikembangkan sebagai salah satu media yang menarik dan menyenangkan serta dapat mempermudah guru dalam menyampaikan materi pembelajaran terutam dalam pembelajaran jarak jauh atau online (Budiono, Hakim, \& Afandi, 2021; Riyanto \& Yunani, 2020). Hasil penelitian lainnya, penggunaan video pembelajaran efektif dalam memperdalam pemahaman peserta didik terhadap suatu materi (Ariaji, Nasirsah, \& Siregar, 2020). Dari sisi pesertaa didik, video pembelajaran lebih disukai karena materi lebih mudah dipahami bila terdapat suara dan animasi.

\section{Refleksi}

Kegiatan selanjutnya adalah refleksi hasil penelitian dan para peserta juga memberikan evaluasi akan pelatihan ini. Evaluasi hasil dilihat dari tugaspraktik para peserta yang ada.Hasil praktiknya dinilai dan hal itumenggambarkankeberhasilan materi yang telah disajikan. Selain itu, secara proses juga dicermati kinerjadankesertaanparapeserta.

Setelah kegiatan pelatihan berakhir, tim pelaksana memberikan instrumen angket respon peserta terhadap kegiatan pelatihan. Angket diberikan pada 25 peserta pelatihan, dengan indikator angket yaitu, materi pelatihan, pelaksanaan pelatihan, pemateri atau narasumber, respon terhadap keseluruhan pelatihan dan lanjutam materi. Tabel 1. berikut merupakan hasil angket peserta pelatihan. 
Tabel 1. Hasil Angket Respon PKM

\begin{tabular}{|c|c|c|c|c|}
\hline \multirow{2}{*}{ No } & \multirow{2}{*}{ Pernyataan } & \multicolumn{3}{|c|}{ Persentase( $\%)$} \\
\hline & & TS & $S$ & SS \\
\hline 1. & $\begin{array}{l}\text { Materi yang disampaikan dalam PKM ini bagus dan } \\
\text { sesuai dengan kebutuhan Anda }\end{array}$ & & 30 & 70 \\
\hline 2. & Anda merasa antusias dalam mengikuti pelatihan ini. & & 30 & 70 \\
\hline 3. & Pelatihan ini menarik dan tidak membosankan & & 40 & 60 \\
\hline 4. & $\begin{array}{l}\text { Pelatihan ini membantu Anda dalam meningkatkan } \\
\text { kemampuan dalam membuat video pembelajaran. }\end{array}$ & & 30 & 70 \\
\hline 5. & $\begin{array}{l}\text { Pelatihan ini mendukung kompetensi Anda dalam } \\
\text { membuat video pembelajaran. }\end{array}$ & & 50 & 50 \\
\hline 6. & $\begin{array}{l}\text { Pelatihan ini mendukung kompetensi Anda dalam } \\
\text { membuat powerpoint dalam pembelajaran. }\end{array}$ & & 45 & 55 \\
\hline 7. & $\begin{array}{l}\text { Pelatihan PKM ini dilaksanakan dengan waktu yang } \\
\text { terlalu singkat, Anda membutuhkan waktu pelatihan } \\
\text { yang lebih banyak. }\end{array}$ & 10 & 35 & 55 \\
\hline 8. & Pemateri menguasai materi pelatihan dengan baik & & 30 & 70 \\
\hline 9. & $\begin{array}{l}\text { Pemateri menyampaikan materi pelatihan dengan } \\
\text { metode yang baik. }\end{array}$ & & 35 & 65 \\
\hline 10. & $\begin{array}{l}\text { Guru perlu dibekali pelatihan ini agar dapat membuat } \\
\text { pembelajaran yang lebih bervariasi. }\end{array}$ & & 45 & 55 \\
\hline
\end{tabular}

Menurut semua peserta, pelatihan ini sangat bermanfaat karena dapat memudahkan guru untuk menjelaskan materi pembelajaran. Selanjutnya menambah wawasan dalam kegiatan pembelajaran daring di masa pandemi ini agar peserta didik tidak bosan dalam mempelajari materi yang diberikan guru. Hal ini sejalan dengan kegiatan hasil pelatihan yang menyatakan pemanfaatan media pembelajaran berbasis IT dengan menggunakan software camtasia dapat meningkatkan pengetahuan dan keterampilan guru (Aflahah, Hefni, \& Fawaid, 2020).

\section{Evaluasi Kegiatan}

Kegiatan pengabdian kepada masyarakat ini menunjukkan bahwa pelatihan pembuatan video pembelajaran bagu guru SMA Karya Ibu Palembang berlangsung dengan lancar dan sukses. Peserta sangat antusias mengikuti seluruh kegiatan pelatihan, termasuk langsung mempraktikkan bagaimana cara membuat video pembelajaran dengan aplikasi camtasia. Beberapa peserta masih ada yang belum menguasai seluruh materi yang diberikan, hal ini menunjukkan bahwa perlu adanya pendampingan dalam pembuatan video pembelajaran.

Dari hasil angket yang diberikan setelah mengikuti kegitan pelatihan ini ternyata memberikan hasil yang positif. Pelatihan ini membantu guru dalam meningkatkan kemampuan dalam membuat video pembelajaran, pelatihan ini mendukung kompetensi guru dalam membuat video pembelajaran dan pelatihan ini mendukung kompetensi guru dalam membuat powerpoint dalam pembelajaran.

\section{KESIMPULAN}

Berdasarkan hasil yang diperoleh dari kegiatan yang telah dilakukan dan berdasarkan respon yang di berikan oleh peserta pelatihan dapat diambil kesimpulan bahwa guruguru SMA Karya Ibu Palembang yang mengikuti pelatihan ini bertambah wawasan, pengetahuan dan keterampilannya dalam membuat video pembelajaran. Dari hasil 
kegiatan yang telah diperoleh, dapat diberikan saran sebagai berikut : (1) Perlu dilakukan tindak lanjut dari kegiatan ini berupa pembuatan video yang diupload atau dipublikasikan; (2) perlu dilakukan kegiatan pelatihan lanjutan terutama melatih keterampilan guru untuk mengukur aspek apektif dan psikomotorik.

\section{UCAPAN TERIMA KASIH}

Ucapan terima kasih kami sampaikan kepada Universitas PGRI Palembang yang telah mendanai PKM ini.

\section{DAFTAR PUSTAKA}

Abdullah, R. (2017). Pembelajaran dalam persfektif kreativitas guru dalam pemanfaatan media pembelajaran. Lantanida Journal, 35-49.

Aflahah , A., Hefni, M., \& Fawaid, A. (2020). Pelatihan Pembuatan Media Pembelajaran Berbasis IT Menggunakan Software Camtasia untuk Guru Alumni PGMI Fakultas tarbiyah. PERDIKAN (Journal of Community Engagement), 2(2), 54-65.

Al Azhari, R. H., \& Al-Rashdi, M. H. (2014). the Effect Of Using Authentic Materials In teaching. International Journal Of Scientific \& technology Reasearch, 3(10), 249-254.

Ariaji, R., Nasirsah, N., \& Siregar, S. A. (2020). Pengembangan Video Pembelajaran Kimia Sma/Ma Menggunakan Camtasia Studio 8. Jurnal Penelitian dan Pembelajaran MIPA, 5(1), 55-64.

Budiono, A. N., Hakim, M., \& Afandi, B. (2021). Pelatihan Pembuatan Video Pembelajaran Menggunakan Camtasia Bagi Guru Ma'arif Jember Di Era Pandemi . ABDI KAMI: Jurnal Pengabdian Kepada Masyarakat, 225-20.

Ekayani, N. P. (2017). Pentingnya penggunaan media pembelajaran untuk meningkatkan prestasi belajar siswa. Jurnal Fakultas Ilmu Pendidikan Universitas Pendidikan Ganesha Singaraja, 2(1), 1-11.

Hafizh, M. A. (2017). Pengembangan Video Pembelajaran Berbantu Camtasia Studio Pada Materi Perkembangan Teknologi Kelas IV SD. Elementary School Journal PGSD Fip Unimed, 141-154.

Herliandry, L. D., Nurhasanah, N., Suban, M. E., \& Kuswanto, H. (2020). Pembelajaran pada masa pandemi covid-19. Jurnal Teknologi Pendidikan, 22(1), 65-70.

Hernawan, A. H., Permasih, \& Dewi, L. (2012). Pengembangan Bahan Ajar. Direktorat UPI Bandung, 4(11).

Kamlin, M., \& Keong, T. C. (2020). Adaptasi video dalam pengajaran dan pembelajaran. Malaysian Journal of Social Sciences and Humanities (MJSSH), 5(10), 105-112.

Masdul, M. R. (2018). Komunikasi pembelajaran. IQRA Jurnal Ilmu Kependidikan Dan Keislaman,. Jurnal Ilmu Kependidikan Dan Keislaman, 13(2), 1-9.

Prastowo, A. (2014). Pengembangan Bahan Ajar Tematik. JAkarta: Kencana Prenadamedia Group.

Priwantoro, S. W., Fahmi, S., \& Y, D. A. (2019). Pelatihan Peningkatan Kemampuan ITBagi Guru Matematika Menggunakan Geogebra. Jurnal Erapan Abdimas, 203-209.

Putra, I., Ariawan, K. U., \& Sutaya, W. (2019). Pengembangan media pembelajaran berbasis Camtasia Studio video CD interaktif multimedia untuk mata pelajaran pemrograman web di jurusan multimedia SMK Negeri 3 Singaraja. Jurnal Pendidikan tTeknik Elektro Undiksha, 6(1), 1-8.

Riyanto, A., \& Yunani, E. (2020). ). the Effectiveness of Video As a Tutorial Learning Media in Muhadhoroh Subject. Akademika: Jurnal eknologi Pendidikan, 9(02), 73-80.

Rohmawati, A. (2015). Efektivitas pembelajaran. Jurnal Pendidikan Usia Dini, 9(1), 15-32. 
Sadjati, I. M. (2003). "Jenis Media Cetak Non Cetak", dalam ian Belawati, dkk, Pengembangan Bahan Ajar. Jakarta: Universitas Terbuka.

Soleh, M., \& Suraya, S. (2018). Pelatihan Pembuatan Bahan Ajar Berbasis Teknologi Informasi Dengan Camtasia Studio Bagi Guru Di Smk Muhammadiyah 2 Muntilan-Magelang. Jurnal terapan Abdimas, 192-199.

Suardi, M. (2015). Belajar E pembelajaran. Yogyakarta: Deepublish.

Suwardana, H. (2018). Revolusi Industri 4. 0 Berbasis Revolusi Mental. JAI UNIK: Jurnal Ilmiah teknik Dan Manajemen Industri, 1(2), 109-118.

Tafonao, T. (2018). Peranan media pembelajaran dalam meningkatkan minat belajar mahasiswa. Jurnal Komunikasi Pendidikan, 2(2), 103-114.

Thohari, A. N., Wibowo, A. W., Santoso, K., Aji, N. B., Rochmatika, R. A., Kartika, V. S., .. . Lathief, M. F. (2021). Pelatihan Pembuatan Video Interaktif Menggunakan Camtasia Untuk Media Pembelajaran di Smk Robbi Rodliyya. Community Development Journal: Jurnal PEngabdian Masyarakat, 2(2), 310-313.

Wahyuni, L. G., Adnyani, L. D., \& Pratiwi, N. P. (2020). Media Pembelajaran Digital Berbantuan Studio Camtasia. Proceeding Senadimas Undiksha, (p. 1576).

Dr. Nyiayu Fahriza Fuadiah, S.Si., M.Pd

Universitas PGRI Palembang,

Jl. Seruni No.14A Bukit Lama, Palembang, Sumatera Selatan 30139, Indonesia

Email: nyiayufahriza@univpgri-palembang.ac.id

*Marhamah, M.Pd (Corresponding Author)

Universitas PGRI Palembang,

Jl. Puncak Sekuning Lr Swadaya RT 19 RW 05 No.1125, Palembang, Sumatera Selatan

30137, Indonesia

Email : marhamah1904@gmail.com

Eka Fitri Puspa Sari, M.Pd

Universitas PGRI Palembang,

Jl. Kancil Putih 6 No.4625, Palembang, Sumatera Selatan 30137 Indonesia

Email: ekafitrips@univpgri-palembang.ac.id

Dra. Jumroh, M.Pd

Universitas PGRI Palembang

Jln Jendral A.Yani Komplek Villa Azhar Blok J9, Palembang, Sumatera Selatan 30165,

Indonesia

Email : jumrohdahlan@gmail.com

Dra. Lusiana, M.Pd

Universitas PGRI Palembang

Jl.Jaya Indah Lrg Rukun 2. no. 1075 Rt21 Rw7,kel.14 Ulu,kec seberang Ulu 2, Palembang 30264, Sumatera Selatan, Indonesia

Email: luu.sii.ana@gmail.com 